\title{
Elucidation of Biochemical Mechanism Involved in Microbial Degradation of 1:1 Metal Complex Dye Containing Simulated Wastewater
}

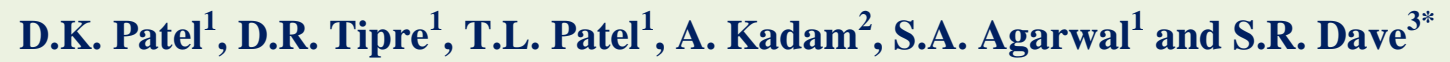 \\ ${ }^{1}$ Department of Microbiology and Biotechnology, School of Sciences, Gujarat University, \\ Ahmedabad 380009, Gujarat, India \\ ${ }^{2}$ Dongguk University, Department of Life Sciences, South Korea \\ ${ }^{3} X R F$, Loyola Centre for $R \&$ D, Xavier college campus, Ahmedabad 380009, Gujarat, India \\ *Corresponding author
}

\section{A B S T R A C T}

\begin{tabular}{|c|}
\hline Keywords \\
\hline $\begin{array}{l}\text { Decolourization, } \\
\text { Toxicity, } \\
\text { Consortium, Metal } \\
\text { complex dyes }\end{array}$ \\
\hline Article Info \\
\hline $\begin{array}{l}\text { Accepted: } \\
24 \text { February } 2018 \\
\text { Available Online: } \\
10 \text { March } 2018\end{array}$ \\
\hline
\end{tabular}

A developed bacterial consortium showed potential for decolourization of two simulated wastewaters containing 1:1 metal complex acid dyes namely, Acid blue 158 and Acid black 52, separately. Ability of decolourization was found up to $1300-1650 \mathrm{mg} \mathrm{L}^{-1}$ of cumulative dye concentration in a fed batch system along with faster decolourization rate in batch mode at $100 \mathrm{mg} \mathrm{L}^{-1}$ concentration. Chromium removal efficiency of consortium showed metal sorption on bacterial cells. Oxidoreductive enzymes that are laccase, lignin peroxidase, tyrosinase, azoreductase and NADH-DCIP reductase were involved in the degradation of dyes. UV-Vis spectra, HPLC and FTIR analysis confirmed the biodegradation of the dyes. $\mathrm{H}^{1} \mathrm{NMR}$ and GC-HRMS analysis supported the prediction of possible biodegraded metabolites produced, on the basis of which degradation pathways were proposed with possible degradation intermediates. Reduced phytotoxicity was observed after treatment for Cicer aeriatinum whereas S. bicolor showed induced growth. Similarly, reduced microbial toxicity was observed (15-37\%) for $S$. aureus and $P$. aeruginosa, both.

\section{Introduction}

Metal complex azo dyes (MCADs) are one of an important class of azo dyes, which include chromium, cobalt, nickel and copper complexed with azo ligands (Ghosh et al., 2014; Hunger, 2003). These dyes are often used in wool and nylon industries with simultaneous generation of highly coloured effluents that cause environmental damages along with adverse effects on various life forms. Thus, it needs suitable treatment prior to their disposal. Conventional treatment techniques have high capital and operating costs as well as they results in incomplete removal of pollutant compounds of dyes (Ghosh and Das, 2012 ; Chen et al., 2015).

Moreover, many of methods leads to generation of secondary pollutants and high quantity of sludge pause further problems (Solis et al., 2012). Biological treatment methods require low energy and make the process cost effective (Saratale et al., 2011). 
Bioremediation of heavy metals and dyes separately has been explained by Shrivastava (2012). However, very little information is available on simultaneous removal of colour along with metals from metal complex dyes. Further, ability of bacterial cells has been proven for the removal of metals and colour which is reported by Ghosh et al., (2014). Decolourization of 18 different metal complex acid dyes using various bacterial consortia was explored in our earlier report along with detailed study of MCAD's degradation pathways and characterization (Patel et al., 2017). Hence, the present study was undertaken to illustrate biodegradation pathway and detoxification of simulated waste containing 1:1 chromium complex Acid blue 158 (AB158) and Acid black 52 (AB52) dyes using a developed bacterial consortium, separately.

\section{Materials and Methods}

\section{Dyes, media and chemicals}

MCADs used in the study (AB158 and AB52) were gifted by Apex dyestuff Ltd., Vatva, Ahmedabad, Gujarat, India. Nutrient broth (NB) purchased from Hi Media, India, was used. If otherwise mentioned, 1:10 diluted NB was used in the experiments. Chemicals including methyl red, ABTS (2,2-azinobis (3ethylbenzothiazolin-6-sulphonic acid)), NADH (Nicotinamide adenine dinucleotide hydrogen), DCIP (Dichloro phenol indophenol) and other chemicals were purchased from Merck, India.

\section{Simulated wastewater preparation}

Simulated wastewater was prepared which is containing both the MCADs, separately. The $\mathrm{pH}$ of the final solution was adjusted to $7 \pm 0.4$ using $1 \mathrm{~N} \mathrm{HCl}$ or $\mathrm{NaOH}$. Concentration of MCADs was $50 \mathrm{mg} \mathrm{L}^{-1}$ and changed depending on the experimental needs.
Consortium development, maintenance and preservation

A consortium denoted as SDG was indigenously developed for degradation of MCADs as mentioned elsewhere (Patel et al., 2017). It was enriched, maintained and preserved in nutrient broth containing mixture of MCADs (50 $\left.\mathrm{mg} \mathrm{L}^{-1}\right)$.

\section{Fed batch decolourization of MCADs and effect of adaptation}

Fed batch biodecolourization study on was carried out separately in $250 \mathrm{~mL}$ Erlenmeyer flasks with $100 \mathrm{~mL}$ NB supplemented with 50 $\mathrm{mg} \mathrm{L}^{-1}$ initial MCAD concentration and inoculated with $10 \%(\mathrm{v} / \mathrm{v})$ having $3 \times 10^{8}$ cells $\mathrm{mL}^{-1}$ as inoculum. After decolourization of $>80 \%$ of MCAD, next lot was added at a concentration of $50-150 \mathrm{mg} \mathrm{L}^{-1}$ in the same ongoing system. The cumulative MCAD concentration for $\mathrm{AB} 158$ and AB52 was 1650 and $1300 \mathrm{mg} \mathrm{L}^{-1}$ at the end of the experiment in 17 and 15 instalments, respectively. The addition of MCAD was continued till the decolourization efficiency reduced below $50 \%$ after $96 \mathrm{~h}$ of contact time. In next experiment, 'fed batch adapted' and 'unadapted consortium' (original consortium) were studied for their decolourization efficiency of both the MCADs in batch mode (batch culture) with $100 \mathrm{mg} \mathrm{L}^{-1}$ MCAD concentration in nutrient broth separately under optimum physico-chemical conditions for dye decolourization which is reported elsewhere (Patel et al., 2017). Decolourization experiments were followed by degradation study where one of the important steps is removal of metal from the MCADs under study.

\section{Metal removal study}

Removal of chromium by the consortium was studied by estimating total chromium in the 
treated and untreated system. A test system containing $100 \mathrm{~mL} \mathrm{NB}$ was prepared with 500 $\mathrm{mg}$ of MCAD and inoculated with $10 \%(\mathrm{v} / \mathrm{v})$ inoculum containing $3 \times 10^{8}$ cells along with abiotic control. Metal content was analysed when decolourization reached $>90 \%$ for test system. Similarly, metal content from coloured abiotic system was also analysed. The total amount of biomass was obtained from the system by centrifugation at $5000 \mathrm{~g}$. Estimation of chromium sorbed on bacterial cell mass after biological treatment was carried out by analysis of aqua regia digested cell mass using Atomic Absorption Spectrophotometer (AAS) (Model SL-243, Elico, India) (Vogel, 1962).

\section{Preparation of cell free extract}

Activated consortium was subjected to grow in $250 \mathrm{~mL}$ Erlenmeyer flasks containing 100 $\mathrm{mL}$ NB incubated at $35 \pm 2{ }^{\circ} \mathrm{C}$ under static condition in the presence of both the MCADs, individually. The cells were pelleted by centrifugation at $5000 \mathrm{~g}$ for $10 \mathrm{~min}$. The supernatant was used as extracellular enzyme fraction. The cell pellet was resuspended in potassium phosphate buffer (50 mM, pH 7.4) and sonicated at an output of $80 \mathrm{~W}$ with ten strokes each of 30 s with a 2 min interval at $4^{\circ} \mathrm{C}$. The cell debris was then separated by centrifugation at $5000 \mathrm{~g}$ for $10 \mathrm{~min}$ at $4^{\circ} \mathrm{C}$. The obtained supernatant was used as the intracellular enzyme fraction. Control was analysed from the control flask that was run in parallel with the same culture conditions without the addition of dye in the system.

\section{Enzyme assays}

Induction of various oxidoreductive enzymes while decolourization MCADs is one of the way to confirm biodegradation of MCADs. Hence, activity of oxidoreductive enzymes was checked for Azoreductase (Zimmermann et al., 1982), NADH-DCIP reductase (Lade $e t$ al., 2012), Laccase (Agrawal et al., 2014), Lignin peroxidase (Kalyani et al., 2008) and Tyrosinase (Kadam et al., 2011) enzyme. One unit of reductive enzyme activity was defined as the amount of enzyme required to reduce $1 \mu \mathrm{M}$ substrate per minute. One unit of oxidative enzyme was defined as the amount of enzyme to increase 1.0 absorbance unit under the standard assay conditions.

\section{Biodegradation studies and pathway elucidation}

Induced enzymes acted on MCAD molecule and broken down the molecule depending on the specificity of the type of enzyme. Depending on the enzymatic cleavage mechanism, a pathway responsible for MCAD degradation was elucidated. For that, spectral differences of UV-Vis, FTIR and HPLC analysis were studied by analysing dye containing system along with control (without dye) after centrifugation at 12,000 $\mathrm{g}$ for 10 min. The peak differences between untreated and treated dye was recorded using UV-Vis spectrophotometer (model 630V, Jasco, Japan). The decolourized broth after cell separation was extracted twice using double volumes of ethyl acetate and concentrated in a rotary vacuum evaporator (Adnan et al., 2014). The metabolite concentrate was dissolved in HPLC grade methanol at the time of analysis. Further, $\mathrm{H}^{1} \mathrm{NMR}$ and GC-HRMS studies were carried out from the same sample to confirm the degradation and metabolite identification. HPLC analysis was carried out on Shimadzu LC solutions with reverse phase C18 column using a pre-mixed degassed mobile phase of $70 \%$ aqueous acetonitrile with $5 \mathrm{mM}$ ammonium acetate by isocratic method with 15 min run time (Lemr et al., 2000). FTIR analysis was carried out using FTIR spectrophotometer (Bruker, Germany) in the mid IR region of $600-4000 \mathrm{~cm}^{-1}$ with 16 scan speed (Saratale et al., 2009). Proton NMR $\left({ }^{1} \mathrm{H}\right.$ NMR) analysis was carried out to study the 
biotransformation of the dye molecule before and after decolourization of MCADs using a $300 \mathrm{MHz}$ NMR spectrometer (Varian, Mercury plus NMR spectrophotometer, USA) at $25 \pm 2{ }^{\circ} \mathrm{C}$ temperature using $5 \mathrm{~mm}$ auto switchable probe with methanol solvent. GCHRMS was carried out on Agilent 7890 with FID and high resolution mass analyzer of Jeol, AccuTOF GCV. In gas chromatography, Resteck column $(0.25 \mathrm{~mm}$ x $30 \mathrm{~mm}$, XTI-5) with a temperature programming mode was used (Kabra et al., 2011b).

\section{Phytotoxicity}

MCADs before and after treatment were suspended in the distilled water to get final concentration of $1000 \mathrm{mg} \mathrm{L}^{-1}$ for $\mathrm{AB} 158$ and $500 \mathrm{mg} \mathrm{L}^{-1}$ for AB52. The concentration of MCADs was decided on the basis of the observations of seed germination in different concentrations of MCADs before conducting the experiment. The prepared solution was applied to the viable seeds of Sorghum bicolor and Cicer aeriatinum (procured from local market) plants using garden soil and added with $10 \mathrm{~mL}$ of solution every day for $10 \mathrm{~d}$ for each of the treatment including untreated MCADs, treated MCADs and distilled water (as a control). The effects were recorded in terms of seed germination, length of root (plumule) and length of the shoot (radical) after $10 \mathrm{~d}$ (Patel et al., 2015).

\section{Microbial toxicity}

$P$. aeruginosa and $S$. aureus cultures (procured from the departmental culture collection) were chosen as the test organisms to study the microbial toxicity of the control dye and its degraded products at an equal proportion. $\mathrm{LD}_{50}$ was decided for MCADs and on the basis of that $500 \mathrm{mg} \mathrm{L}^{-1}$ concentration was selected for $\mathrm{AB} 158$ and $250 \mathrm{mg} \mathrm{L}^{-1}$ concentration was selected for $\mathrm{AB} 52$. Well plate assay was performed to determine the zone of inhibition after $24 \mathrm{~h}$ of incubation at $35 \pm 2{ }^{\circ} \mathrm{C}$ at equal concentrations of treated and untreated dye solutions and distilled water (as a control) (Patel et al., 2017).

\section{Results and Discussion}

\section{Bacterial consortium characterization}

Bacterial consortium was characterized on the basis of culture dependent approach and isolated bacterial species were identified using $16 \mathrm{~s}$ rRNA gene sequencing. Developed bacterial consortium showed the presence of Pantoea ananatis (KM502538), Bacillus fortis strain E4 Pb3 (KM502537), Alcaligenes faecalis (KM502541), Brevibacillus parabrevis strain GRG (KM502542) and Bordetella trematum (KP751929) bacterial species (Patel et al., 2017).

\section{Fed batch decolourization and effect of adaptation}

Decolourization of MCADs as continuous dye addition in the range of $50-150 \mathrm{mg} \mathrm{L}^{-1}$ per instalment in the same system showed $80-90 \%$ decolourization up to 12 cycles of dye addition irrespective of dyes and dye concentration used (Fig. 1). After that, reduction in the decolourization was observed in all cases. It is worth noting that the total concentration of dye added to each system was 1300 and $1650 \mathrm{mg} \mathrm{L}^{-1}$ up to 15 and 17 cycles in case of AB52 and AB158, respectively. It was observed that decolourization rate increased in the initial cycles and afterwards it became constant upto12 $2^{\text {th }}$ cycle irrespective of MCAD used. In case of both the MCADs studied, very fast decolourization was observed in the initial hours of incubation and in case of AB158 nearly $80-85 \%$ decolourization was achieved in just $5 \mathrm{~h}$ (data not shown). Reduced ability of bacterial consortium after several cycles of dye addition may be attributed to nutrient 
scarcity and entry of consortium in stationary or death phase of growth. In fed batch study, Dave and Dave (2009) have reported > 90\% decolourization up to 5 cycles with cumulative dye concentration of $1500 \mathrm{mg} \mathrm{L}^{-1}$ at the 5 th cycle in case of AR119, which was found to reduce thereafter, whereas more than $90 \%$ decolourization was achieved till the $9^{\text {th }}$ cycle with $2700 \mathrm{mg} \mathrm{L}^{-1}$ of Reactive red BS and after that reduced decolourization rate was recorded (Sheth and Dave, 2009). Jadhav et al., (2012) observed a similar trend where decolourization time was increased with reduced decolourization efficiency upon increase in concentration of Remazol orange.

Inoculum obtained from fed batch decolourization experiment system showed increased efficiency towards decolourization as compared to unadapted consortium (Fig. 2) where $100 \mathrm{mg} \mathrm{L}^{-1}$ of dye was decolourized in the range of $55-60 \%$ in $24 \mathrm{~h}$ of incubation whereas fed batch adapted consortium showed more than $90 \%$ decolourization i.e. $\sim 1.5$ fold better efficiency. Increased dye decolourization efficiency might be due to adaptation of organisms to high dye concentration. Abd El-Rahim et al., (2003) have also reported the beneficial effect of adaptation, even for the organisms isolated from heavily dye polluted sites.

\section{Metal removal study}

Removal of chromium was recorded after the treatment of dyes using bacterial consortium (Table 1). Initially $51.8 \pm 1.34$ and $55.8 \pm 1.21$ $\mathrm{mg}$ of chromium was present in untreated $\mathrm{AB} 52$ and $\mathrm{AB} 158$, respectively, whereas after decolourization amount of chromium was below the detectable limits. However, aqua regia digested cell mass recovered after decolourization showed the presence of chromium in the range of $40.92 \pm 1.82$ to 45.0 $\pm 0.57 \mathrm{mg}$ for AB52 and AB158, respectively, which was nearly $73-87 \%$ of total chromium found in the system. This proved the chromium biosorption ability of consortium from the system during biodegradation of dyes. Removal of metal from the MCADs was followed by its decolourization. Further studies after biodecolourization and metal removal were, analysis of biodegradation and enzymatic influence responsible for biodegradation.

\section{Enzyme analysis}

Various oxidoreductive enzymes were found induced during the course of decolourization process (Table 2). The highest induction was observed for intracellular NADH-DCIP reductase, which showed more than $320 \%$ increase than the control system, followed by azoreductase, and other enzymes. Role of laccase and azoreductase enzymes are explained for degradation of Reactive orange 16 (Jadhav et al., 2010). The presence of various degradative enzymes including azoreductase, DCIP reductse, laccase, veratryl alcohol oxidase, lignin peroxidase and tyrosinase was studied in consortium (Lade et $a l ., 2015)$ as well as in individual bacterial species (Wang et al., 2007; Mabrouk et al., 2008; Shah et al., 2012; Shi et al., 2015; Gonzalo et al., 2016).

\section{Biodegradation analysis and degradation pathway elucidation}

MCADs biodegradation was investigated using HPLC, FTIR, $\mathrm{H}^{1} \mathrm{NMR}$ and GC-HRMS analysis of control and biodegraded MCADs. Similarly, degradation of Navy blue HE2R using adventitious root culture was analysed by FTIR (Santos and Corso, 2014) and GCMS spectrometry (Patil et al., 2016). The detailed HPLC elution profile of MCADs before and after degradation is given in the Table 3. Control spectra of AB 158 and AB 52 showed 9 and 5 peaks of different height and at different retention time (RT), respectively. 
Table.1 Metal removal during biodegradation of MCADs

\begin{tabular}{|l|c|c|c|}
\hline \multirow{2}{*}{ MCAD } & \multicolumn{3}{|c|}{ Chromium concentration (mg) in various samples } \\
& $\begin{array}{c}\text { Untreated Dye } \\
\mathbf{( 5 0 0 m g )}\end{array}$ & $\begin{array}{c}\text { Medium after } \\
\text { treatment }\end{array}$ & Digested cell mass \\
\hline AB158 & $55.8 \pm 1.21$ & BDL & $40.92 \pm 1.82$ \\
\hline AB52 & $51.8 \pm 1.34$ & BDL & $45.0 \pm 0.57$ \\
\hline
\end{tabular}

(BDL - Below detectable limit).

Table.2 Variations in induction of enzymes due to the presence of MCADs

\begin{tabular}{|l|c|c|}
\hline \multirow{2}{*}{ Enzyme } & \multicolumn{2}{|c|}{ Enzyme induction (\%) } \\
\hline Azoreductase & AB158 & AB52 \\
\hline NADH-DCIP reductase & 255.0 & 270.0 \\
\hline Lignin peroxidase & 320.0 & 346.7 \\
\hline Intracellular & & \\
\hline Extracellular & 157.0 & 154.8 \\
\hline Tyrosinase & 151.1 & 157.4 \\
\hline Laccase & 139.1 & 130.4 \\
\hline
\end{tabular}

Table.3 HPLC elution peak profile of untreated and biodegraded MCADs

\begin{tabular}{|c|c|c|c|c|}
\hline \multirow{2}{*}{$\begin{array}{c}\text { Peak } \\
\text { number }\end{array}$} & \multicolumn{2}{|c|}{ AB158 } & \multicolumn{2}{c|}{ AB52 } \\
\hline $\mathbf{1}$ & $\mathbf{U T}$ & BD & UT & BD \\
\hline $\mathbf{2}$ & 2.524 & 1.193 & 3.466 & 0.851 \\
\hline $\mathbf{3}$ & 3.448 & 3.930 & 3.916 & 3.926 \\
\hline $\mathbf{4}$ & 3.676 & 4.913 & 4.833 & 4.899 \\
\hline $\mathbf{5}$ & 3.928 & 6.217 & 13.452 & 6.770 \\
\hline $\mathbf{6}$ & 4.357 & 6.814 & 14.215 & 11.126 \\
\hline $\mathbf{7}$ & 4.840 & 8.576 & & 11.796 \\
\hline $\mathbf{8}$ & 5.279 & 9.325 & & 13.428 \\
\hline $\mathbf{9}$ & 13.459 & 11.924 & & 14.209 \\
\hline $\mathbf{1 0}$ & 14.230 & 13.468 & & \\
\hline
\end{tabular}

UT - Untreated BD - Biodegraded 
Table.4 FTIR analysis of untreated and biodegraded MCADs

\begin{tabular}{|c|c|c|c|c|c|c|c|}
\hline \multicolumn{4}{|c|}{ AB158 } & \multicolumn{4}{|c|}{ AB52 } \\
\hline \multicolumn{2}{|c|}{ UT } & \multicolumn{2}{|c|}{ BD } & \multicolumn{2}{|c|}{ UT } & \multicolumn{2}{|c|}{ BD } \\
\hline$\underset{1}{\text { Peak }}(\mathrm{cm}$ & Bond & Peak $\left(\mathrm{cm}^{-1}\right)$ & Bond & Peak $\left(\mathrm{cm}^{-1}\right)$ & Bond & Peak $\left(\mathrm{cm}^{-1}\right)$ & Bond \\
\hline 3558.28 & $\mathrm{OH}-\mathrm{Str}$ & 3328.76 & $\mathrm{OH}-\mathrm{Str}$ & 3387.34 & OH-Str & 3320.81 & OH-Str \\
\hline 3148.44 & C-H-Str & 2949.95 & C-H-Str & 2755.31 & C-H-Str & 2943.94 & C-H-Str \\
\hline 2921.82 & C-H-Str & 2839.60 & C-H-Str & 2333.91 & $\mathrm{NH}+-\mathrm{Str}$ & 2832.10 & C-H-Str \\
\hline 2342.27 & $\mathrm{NH}+-\mathrm{Str}$ & 2112.04 & $\mathrm{NH}+-\mathrm{Str}$ & 2116.44 & $\mathrm{NH}+-\mathrm{Vib}$ & 2521.98 & $\mathrm{NH}+-\mathrm{Str}$ \\
\hline 2096.95 & $\mathrm{NH}+-\mathrm{Vib}$ & 1668.81 & $\mathrm{C}=\mathrm{O}-\mathrm{Str}$ & 1581.64 & $\mathrm{~N}=\mathrm{N}-\mathrm{Str}$ & 1859.85 & $\mathrm{C}=\mathrm{O}-\mathrm{Str}$ \\
\hline 1596.61 & $\mathrm{~N}=\mathrm{N}-\mathrm{Str}$ & 1405.17 & NH+-Def & 1552.23 & $\mathrm{NO}_{2}-\mathrm{Str}$ & 1656.82 & $\mathrm{C}=\mathrm{N}-\mathrm{Str}$ \\
\hline 1542.55 & NH+-Def & 1110.85 & C-OH-Str & 1495.90 & $\mathrm{C}=\mathrm{N}-\mathrm{Str}$ & 1111.77 & C-OH-Str \\
\hline 1505.39 & $\mathrm{NH}_{3}+-$ Def & 1013.76 & $\mathrm{C}-\mathrm{OH}-\mathrm{Str}$ & 1455.12 & $\mathrm{C}=\mathrm{C}-\mathrm{Str}$ & 1019.51 & C-OH-Str \\
\hline 1423.47 & C-H-Def & & & 1398.71 & $\mathrm{~S}=\mathrm{O}-\mathrm{Str}$ & & \\
\hline 1375.16 & C-H-Def & & & 1316.22 & C-N-Vib & & \\
\hline 1143.08 & $\mathrm{~S}=\mathrm{O}-\mathrm{Str}$ & & & 1112.68 & R-O-R-Str & & \\
\hline 1035.21 & $\mathrm{~S}=\mathrm{O}-\mathrm{Str}$ & & & 1042.82 & $\mathrm{C}-\mathrm{OH}-\mathrm{Str}$ & & \\
\hline 882.60 & C-H-Def & & & 881.43 & C-H-Def & & \\
\hline 822.84 & C-H-Def & & & 819.88 & C-H-Def & & \\
\hline 757.77 & C-H-Def & & & 739.62 & C-H-Def & & \\
\hline
\end{tabular}

Def $=$ Deformation, $\mathrm{Vib}=$ Vibration, $\mathrm{Str}=$ Stretching, $\mathrm{UT}=$ Untreated, $\mathrm{BD}=$ Biodegraded

Table.5 GC-HRMS spectral identification of degraded MCADs

\begin{tabular}{|c|c|c|c|}
\hline MCAD & RT (min) & MW/ $(\mathbf{m} / \mathbf{z})$ & Name of metabolites \\
\hline \multirow[t]{12}{*}{ AB158 } & 25.08 & $239(\mathrm{~m} / \mathrm{z}-239)$ & 7-amino-8-hydroxynaphthalene-1-sulfonic acid \\
\hline & NI & 223 & 4-aminonaphthalene-1-sulfonic acid \\
\hline & 30.31 & $143(\mathrm{~m} / \mathrm{z}-141)(+2)$ & Naphthalene-1-amine \\
\hline & 23.60 & $159(\mathrm{~m} / \mathrm{z}-159)$ & 2-aminonaphthalene-1-ol \\
\hline & 19.81 & $128(\mathrm{~m} / \mathrm{z}-128)$ & Naphthalene \\
\hline & 19.81 & $144(\mathrm{~m} / \mathrm{z}-141)(+3)$ & Naphthalene-1-ol \\
\hline & 23.60 & $160(\mathrm{~m} / \mathrm{z}-159)(+1)$ & Naphthalene-1,2-diol \\
\hline & 20.26 & $122(\mathrm{~m} / \mathrm{z}-125)(-3)$ & 2-hydroxybenzaldehyde \\
\hline & 32.77 & $110(\mathrm{~m} / \mathrm{z}-112)(-2)$ & Pyrocatechol \\
\hline & 19.81 & $114(\mathrm{~m} / \mathrm{z}-113)(+1)$ & 2-oxopent-4-enoic acid \\
\hline & 30.31 & $88(\mathrm{~m} / \mathrm{z}-91)(-3)$ & Pyruvic acid \\
\hline & 19.81 & $44(\mathrm{~m} / \mathrm{z}-44)$ & Acetaldehyde \\
\hline \multirow[t]{12}{*}{$\mathbf{A B 5 2}$} & 23.91 & $159(\mathrm{~m} / \mathrm{z}-159)$ & 1-aminonaphthalene-2-ol \\
\hline & 32.04 & $144(\mathrm{~m} / \mathrm{z}-141)$ & Naphthalene-1-ol \\
\hline & 23.91 & $160(\mathrm{~m} / \mathrm{z}-159)(+1)$ & Naphthalene-1,2-diol \\
\hline & 25.63 & $284(\mathrm{~m} / \mathrm{z}-283)(+1)$ & 4-amino-3-hydroxy-7-nitronaphthalene-1-sulfonic acid \\
\hline & 32.04 & $204(\mathrm{~m} / \mathrm{z}-204)$ & 1-amino-6-nitronaphthalene-2-ol \\
\hline & 32.04 & $189(\mathrm{~m} / \mathrm{z}-189)$ & 6-nitronaphthalene-2-ol \\
\hline & 23.91 & $159(\mathrm{~m} / \mathrm{z}-159)$ & 6-aminonaphthalene-2-ol \\
\hline & 27.72 & $122(\mathrm{~m} / \mathrm{z}-125)(-3)$ & 2-hydroxybenzaldehyde \\
\hline & 32.04 & $110(\mathrm{~m} / \mathrm{z}-112)(-2)$ & Pyrocatechol \\
\hline & 20.37 & $114(\mathrm{~m} / \mathrm{z}-114)$ & 2-oxopent-4-enoic acid \\
\hline & 25.96 & $88(\mathrm{~m} / \mathrm{z}-86)(+2)$ & Pyruvic acid \\
\hline & 20.37 & $44(\mathrm{~m} / \mathrm{z}-43)(+1)$ & Acetaldehyde \\
\hline
\end{tabular}


Table.6 Toxicity study of MCADs and their biodegraded metabolites

\begin{tabular}{|c|c|c|c|c|c|c|c|}
\hline \multirow{2}{*}{\multicolumn{2}{|c|}{$\begin{array}{c}\text { MCADs } \\
\text { Treatments } \\
\text { (Phyto/Microbial toxicity) }\end{array}$}} & \multicolumn{3}{|c|}{ AB158 } & \multicolumn{3}{|c|}{ AB52 } \\
\hline & & Control & UT & BD & Control & UT & BD \\
\hline \multirow[t]{3}{*}{ S. bicolor } & $\mathrm{G}(\%)$ & 100 & 100 & 100 & 100 & 100 & 100 \\
\hline & RL (c & $9.54 \pm 0.38$ & $6.42 \pm 0.73$ & $11.52 \pm 0.98$ & $9.54 \pm 0.38$ & $5.1 \pm 0.64$ & $11.0 \pm 0.55$ \\
\hline & $\mathrm{SL}(\mathrm{cm})$ & $10.46 \pm 0.37$ & $7.06 \pm 0.69$ & $12.12 \pm 0.54$ & $10.46 \pm 0.37$ & $5.58 \pm 0.84$ & $12.34 \pm 0.38$ \\
\hline \multirow[t]{3}{*}{ C. aeriatinum } & $\mathrm{G}(\%)$ & 100 & 80 & 100 & 100 & 40 & 100 \\
\hline & $\mathrm{RL}(\mathrm{cm})$ & $6.52 \pm 0.43$ & $3.82 \pm 0.53$ & $5.06 \pm 0.22$ & $6.52 \pm 0.43$ & $3.95 \pm 0.21$ & $6.6 \pm 0.44$ \\
\hline & $\mathrm{SL}(\mathrm{cm})$ & $6.16 \pm 0.42$ & $4.33 \pm 0.67$ & $6.74 \pm 0.44$ & $6.16 \pm 0.42$ & $4.75 \pm 0.21$ & $6.9 \pm 0.72$ \\
\hline \multicolumn{2}{|c|}{ P. aeruginosa } & NI & $15.1 \pm 0.1$ & $10.17 \pm 0.15$ & NI & $14.27 \pm 0.16$ & $10.13 \pm 0.06$ \\
\hline \multicolumn{2}{|c|}{ S. aureus } & NI & $13.0 \pm 0.6$ & $11.03 \pm 0.15$ & NI & $18.13 \pm 0.06$ & $12.17 \pm 0.21$ \\
\hline
\end{tabular}

$\mathrm{UT}=\mathrm{MCAD}$ before degradation, $\mathrm{BD}=\mathrm{MCAD}$ after degradation, $\mathrm{G}=$ Germination, $\mathrm{RL}=$ Root length, $\mathrm{SL}=$ Shoot length, NI = No Inhibition. Data were statistically analysed with mean value of three sets for each $( \pm$ SEM).

Fig.1 Fed batch decolourization

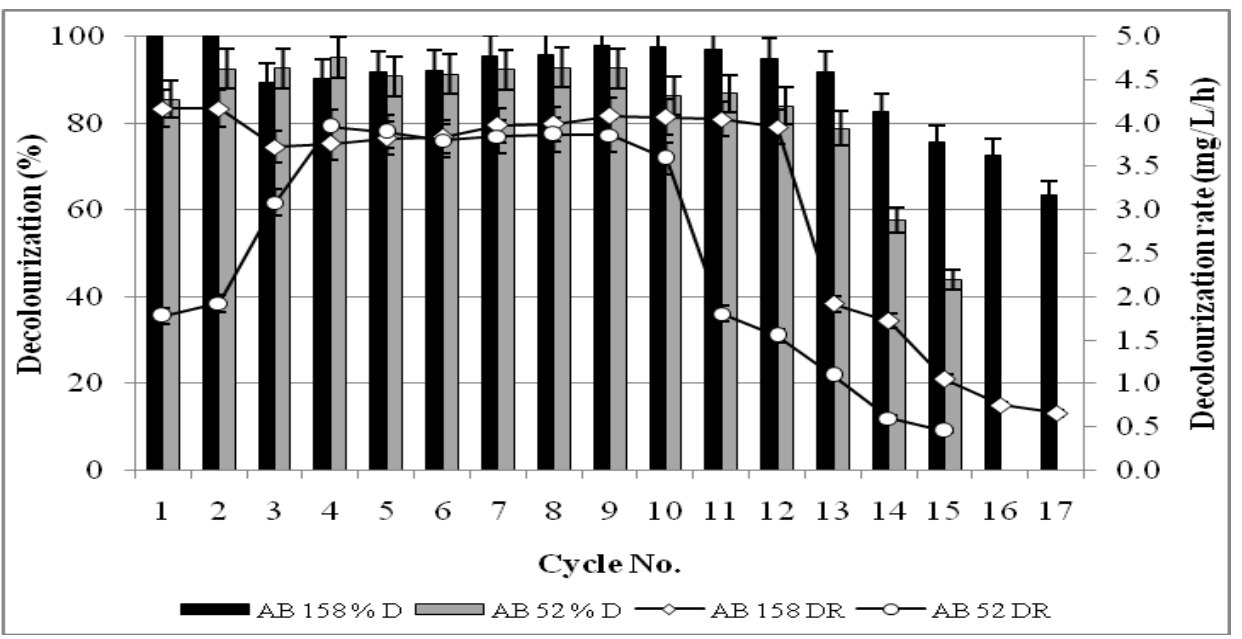

(\% D - Decolourization percentage, DR- Decolourization rate).

Fig.2 Effect of adaptation on decolourization of MCADs

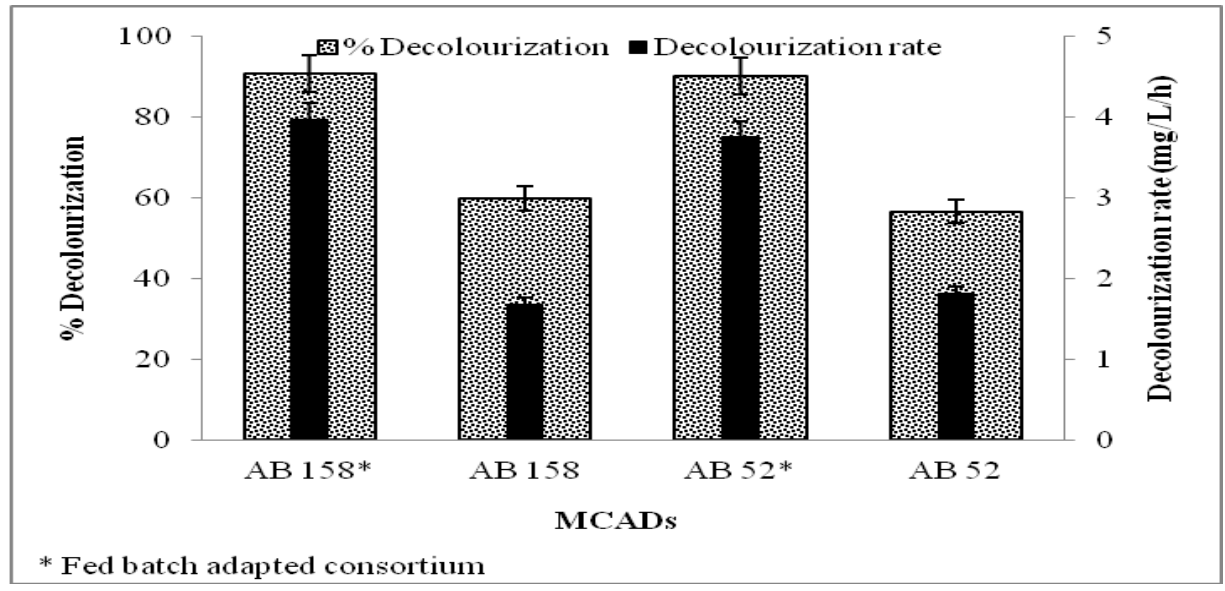


Fig.3 Degradation pathways of MCADs (a) AB 158 (b) AB 52

(a)

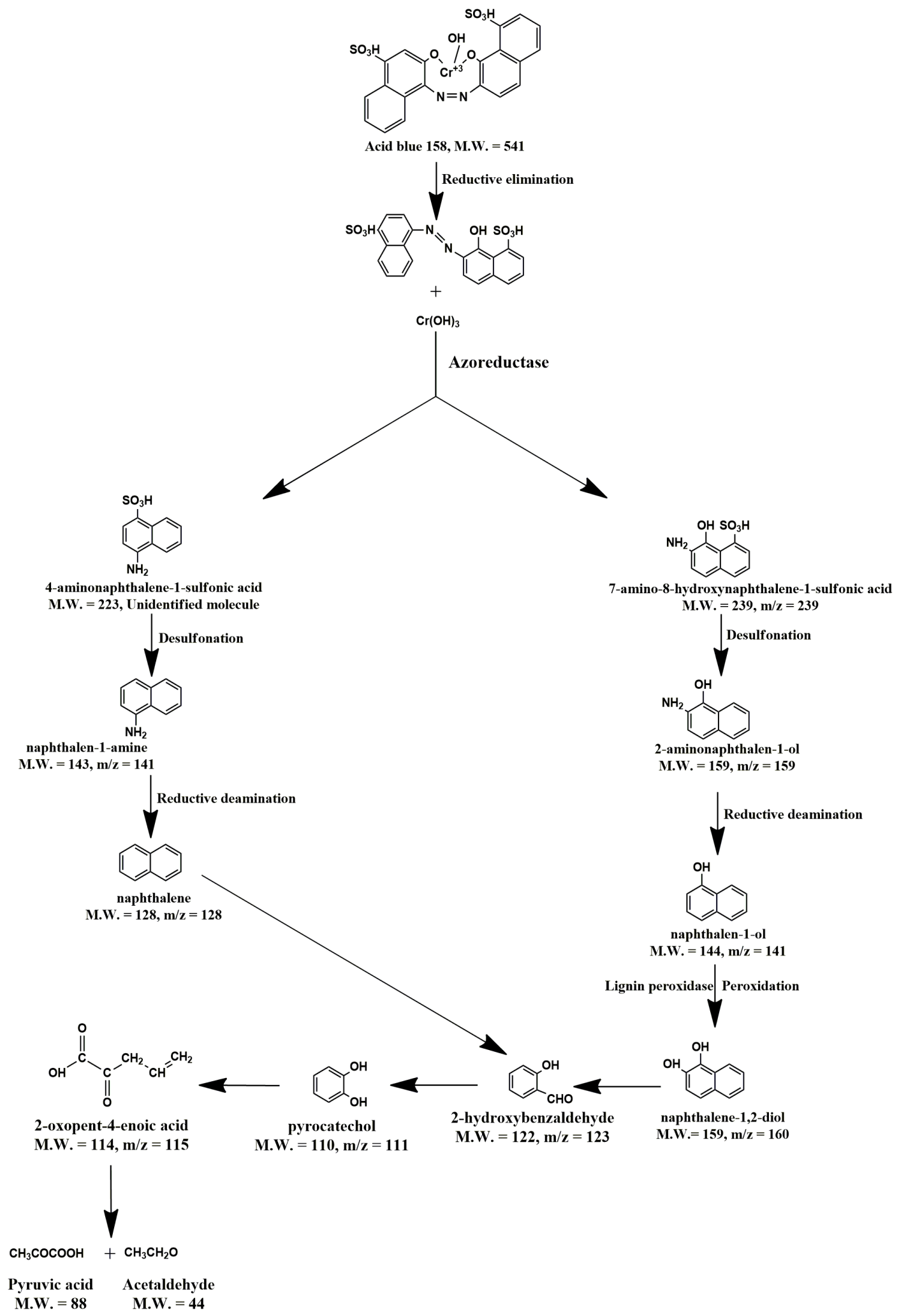


(b)

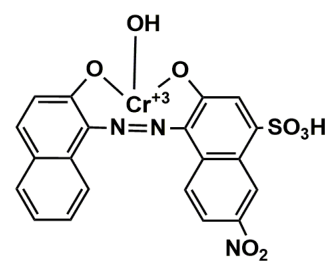

Acid black 52, M.W. $=506$

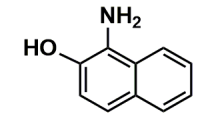

1-aminonaphthalen-2-ol

M.W. $=159, \mathrm{~m} / \mathrm{z}=160$

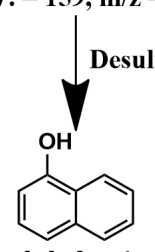

naphthalen-1-ol

M.W. $=144, \mathrm{~m} / \mathrm{z}=144$

Lignin peroxidas $@$ Peroxidation

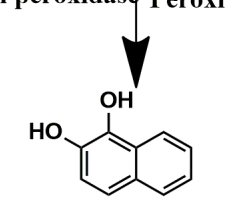

naphthalene-1,2-diol

M.W. $=160, \mathrm{~m} / \mathrm{z}=160$

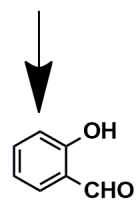

2-hydroxybenzaldehyde

M.W. $=122, \mathrm{~m} / \mathrm{z}=123$

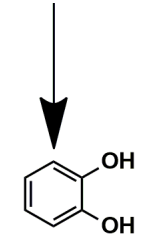

pyrocatechol

M.W. $=110, \mathrm{~m} / \mathrm{z}=111$

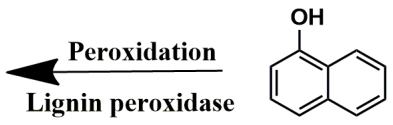

naphthalen-1-ol

M.W. $=144, \mathrm{~m} / \mathrm{z}=144$

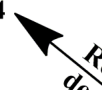

1-amino-6-nitronaphthalen-2-ol

M.W. $=204, \mathrm{~m} / \mathrm{z}=205$

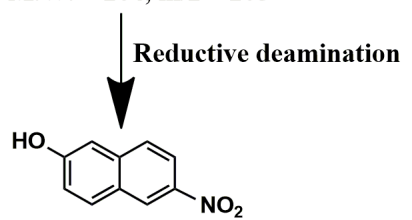

6-nitronaphthalen-2-ol

M.W. $=189, \mathrm{~m} / \mathrm{z}=190$

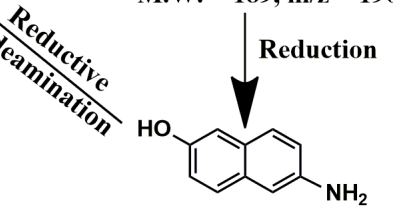

6-aminonaphthalen-2-ol

$M . W .=159, \mathrm{~m} / \mathrm{z}=160$

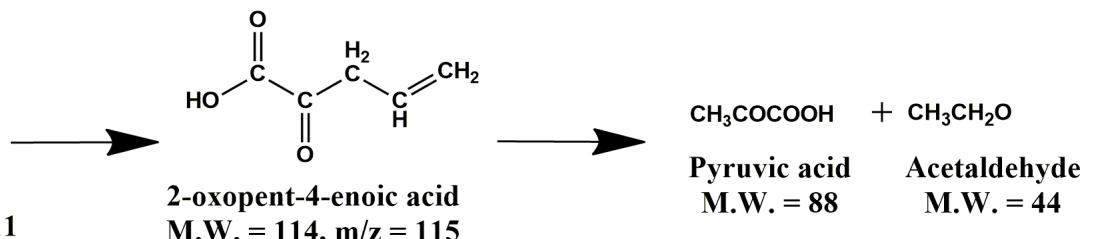


The elution profile of biotreated MCADs showed significant difference in terms of number, height of peaks and RT. In terms of polarity comparison on the basis of RT of control and treated dyes, it was found that treated MCADs were converted to less polar molecules than the original dye molecule, which refers to the removal of various chemical groups from the dye molecule indicating their biodegradation. Disappearance of major peaks at 3.44 and 3.67 RTs of AB158 and 3.47 and 3.93 RTs of AB52 were found in the metabolite fraction. In case of biodegraded MCADs some new peaks have been emerged at 3.93, 4.91, 6.21 and 6.81 RTs of AB158 and3.92, 4.89 and 6.77 RTs of AB 52. Differences in the peak RT profile of treated and untreated dye fraction proved the degradation of dye molecule after developed bacterial treatment. Kadam et al., (2011) have reported differences in the HPLC elution profile as an indication of degradation of dye RBN-HE2R.

The FTIR spectra of MCADs before and after degradation are shown in the Table 4. Appearance of peak at 3558.28 and 3387.34 $\mathrm{cm}^{-1}$ represent the $-\mathrm{OH}$ stretching of asymmetric intra molecular hydrogen bonded phenolic compound in AB158 and AB52, respectively. Moreover, removal of azo bond and change in spectrum profile of MCADs before and after degradation confirmed the degradation of both the MCADs. Disappearance of azo bond representative peak at $1596.61 \mathrm{~cm}^{-1}$ in degraded AB158 dye confirmed the cleavage of azo bond with simultaneous absence of peaks at 2096.95, 1542.55 and $1505.39 \mathrm{~cm}^{-1}$ correspond to $\mathrm{NH}^{+}$ vibration, $\mathrm{NH}^{+}$deformation and $\mathrm{NH}_{3}{ }^{+}$ deformation, respectively.

Peaks representative of $\mathrm{C}-\mathrm{H}$ deformation $\left(1423.47, \quad 1375.16 \mathrm{~cm}^{-1}\right), \quad \mathrm{S}=\mathrm{O} \quad$ stretching $\left(1143.08,1035.21 \mathrm{~cm}^{-1}\right)$ and C-H deformation
(882.60, 822.84, $757.77 \mathrm{~cm}^{-1}$ ) were also absent in the degraded dye with simultaneous change in spectrum profile confirmed the degradation of AB158 dye. In case of degraded dye, the presence of peak at 2112.04 $\mathrm{cm}^{-1}$ represented $\mathrm{NH}^{+}$stretching due to the formation of amines as one of the degradation products with the simultaneous appearance of peaks at 1110.85 and $1013.76 \mathrm{~cm}^{-1}$ corresponding aliphatic alcohol. Various peaks disappeared in the degraded AB52 included 1581.64, 1552.23, 1495.90, 1455.12, 1398.71, 1112.68 and $881.43 \mathrm{~cm}^{-1}$ corresponded to azo bond, $\mathrm{NO}_{2}$ stretching, $\mathrm{C}=\mathrm{N} \quad$ stretching, $\quad \mathrm{C}=\mathrm{C} \quad$ stretching, $\quad \mathrm{S}=\mathrm{O}$ stretching, R-O-R stretching and C-H deformation, respectively. Disappearance of peaks with simultaneous formation of new peaks at $2521.98 \mathrm{~cm}^{-1}$ due to the formation of amine product, $1859.85 \mathrm{~cm}^{-1}$ due to stretching of $\mathrm{C}=\mathrm{O}$ bond and $1111.77 \mathrm{~cm}^{-1}$ due to the formation of aliphatic alcohol confirmed the degradation of dye molecule.

$\mathrm{H}^{1}$ NMR spectra of untreated MCADs showed signals at $\delta 4.88$ and 3.31, which correspond to aromatic ring attached to $\mathrm{O}$ and $\mathrm{N}$ confirmed the presence of oxygen and nitrogen in the structure. Down shift signals were found in the range of $\delta$ 6-9 confirmed the presence of aromatic hydrogen in the structure of MCADs.

Two signals were observed between $\delta$ 0.8-1.4, which agreed the presence of $2^{\circ}$ hydrogen attached to the chelated structure of AB158. However, above mentioned frequencies were found with low signal intensities after degradation of MCADs and new signals emerged in the lower frequency zone of $\delta 0.8$ 2.3 that were due to generation of low molecular weight compounds from high molecular weight compounds including aromatic and aliphatic hydrocarbon along with other free methyl groups, etc. 
Biotransformation study of MCADs based on GC-MS analysis showed the production of probable intermediates (Table 5). On the basis of mass spectral analysis along with enzyme induction study, a pathway is proposed showing possible mechanism of MCADs biodegradation (Fig. 3, a-b). As the biotransformation of MCADs was carried out under microaerophilic condition followed by aerobic condition, the intermediates were further converted into simplest form, which could enter into the central metabolic pathways indicated possible mineralization of the MCADs. The process chemistry can be explained as - the first step in the decolourization of MCADs was separation of chromium ion in the form of chromium hydroxide followed by the cleavage of azo bond by the azoreductase enzyme resulting in the formation of respective aromatic amines. Simultaneously, chromium from the system was sorbed by bacterial consortium. Further deamination (Travkin et al., 2002) and desulfonation (Haug et al., 1991) in the presence of laccase followed by peroxidation resulted into the formation of naphthalene 1,2-diol. Further cleavage of naphthalene 1,2diol under aerobic conditions, resulted in the opening of naphthalene ring via cis-muconic acid pathway, which was further degraded to acetyl CoA using aromatic cleavage pathway for generation of energy through TCA cycle. Similar mechanism for azo dye biodegradation is reported by $\mathrm{Xu}$ et al., (2007). Along with degradation pathway elucidation, it was important to assess the toxicity of generated metabolites upon degradation of native MCAD molecule. Hence, further attention was given to toxicity study of untreated and treated MCADs using plant and bacterial species.

\section{Phytotoxicity}

Phytotoxicity analysis showed reduction in toxic effects of both the MCADs after biodegradation (Table 6). Toxicity was found negligible in the case of S. bicolor as $100 \%$ seed germination was observed whereas in case of $C$. aeriatinum, seed germination was inhibited by 20 and $60 \%$ with untreated AB158 and AB52, respectively.

Untreated MCADs were found inhibitory on both root and shoot lengths where root lengths were inhibited by $33-46 \%$ and $39-41 \%$, whereas shoot lengths were inhibited by 32$47 \%$ and $22-29 \%$ against water control in the case of $S$. bicolor and $C$. aeriatinum, respectively. Biodegraded MCADs showed a growth stimulating effect on root and shoot lengths of both experimental plants except root length of $C$. aeriatinum. Stimulation of growth was recorded in the range of $1-21 \%$ for root and shoot lengths both.

\section{Microbial toxicity}

Toxicity towards growth of test bacterial species reduced in case of degradative metabolites of both the MCADs as compared to the untreated dye both in the case of $S$. aureus and $P$. aeruginosa (Table 6). Size of inhibition zone for control dye ranged from 13-15 mm and 14-18 mm for S. aureus and $P$. aeruginosa, respectively. Reduction in zone of inhibition was noted with treated dye which was in the range of 2 to $6 \mathrm{~mm}$ and 5 to $6 \mathrm{~mm}$ in case of $S$. aureus and $P$. aeruginosa, respectively. Reduction in microbial toxicity is also reported after degradation of AB210 dye (Agrawal et al., 2014).

Biodegradation of $\mathrm{AB} 158$ and $\mathrm{AB} 52$ is explained for which, complete degradation mechanism has not yet been reported. Gradual adaptation process increased degradation rate at even high dye concentrations. The degradation mechanism was found depended on more than one oxido-reductive enzyme. Analytical studies resulted in confirmation of chromium biosorption and possible 
biodegradation mechanism was proposed. Toxicity reduction was observed for bacterial as well as plant systems, which indicated the detoxification potential of consortium for such dye containing wastewaters. Consortium was proved efficient for the treatment of five different actual industrial wastes treatment which leads the study to reactor scale application.

\section{Conflict of interest}

The authors declare that they have no conflict of interest.

\section{Acknowledgement}

Sophisticated analytical instrument facility (SAIF), IIT, Mumbai is duly acknowledged for the analysis of $\mathrm{H}^{1} \mathrm{NMR}$ and GC-HRMS. A generous help from Prof. K. H. Chikhalia and his research students, Department of Chemistry, Gujarat University, Ahmedabad is also acknowledged. The authors also acknowledge Apex Dyestuff Industries, Ahmedabad, for providing MCADs for the study. S. R. Dave has designed research protocol, guided for the research work. D. K. Patel has carried out biodegradation studies and wrote manuscript. D. K. Patel and T. L. Patel conducted the enzyme analysis. S. R. Dave, D. K. Patel, S. Agrawal and A. Kadam contributed in spectral data analysis. S. R. Dave and D. R. Tipre reviewed and corrected the manuscript. All authors read and approved the manuscript.

\section{Funding}

The study was funded by Department of Science and Technology under DST WOS A scheme [SR/WOS A/LS-461/2013]. UGC Emeritus Fellowship is extended to senior author S.R. Dave, [F.6-6/201517/EMERITUS-2015-17-GEN-7433 /(SAII)].

\section{References}

Abd El-Rahim, W.M., Moawad, H. and Khalafallah, M. 2003. Microflora involved in textile dye waste removal. J. Basic Microbiol. 43: 167-174. doi:10.1002/jobm.200390019

Adnan, L.A., Yusoff, A.R.M., Hadibarata, T. and Khudhair, A.B. 2014. Biodegradation of bis-azo dye Reactive Black 5 by white-rot fungus Trametes gibbosa sp. WRF 3 and its metabolite characterization. Water Air Soil Pollut. 225: 2119, 1-11. doi:10.1007/s11270014-2119-2

Agrawal, S., Tipre, D., Patel, B. and Dave, S. 2014. Optimization of triazo Acid Black 210 dye degradation by Providencia sp. SRS82 and elucidation of degradation pathway. Process Biochem. 49(1): 110119. doi:10.1016/j.procbio.2013.10.006

Chen, Z., Chen, H., Pan, X., Lin, Z. and Guan, X. 2015. Investigation of Methylene Blue biosorption and biodegradation by Bacillus thuringiensis 016. Water Air Soil Pollut. 226: 146, 1-8. doi: 10.1007/s11270-015-2417-3

Dave, S.R. and Dave, R.H. 2009. Isolation and characterization of Bacillus thuringiensis for Acid Red 119 dye decolourization. Bioresour. Technol. 100: 249-253. doi:10.1016/j. biortech.2008.05.019

Ghosh, A. and Das Saha, P. 2012. Optimization of copper adsorption by chemically modified fly ash using response surface methodology modeling. Desalination Water Treat. 49(1-3): 218-226. doi:10.1080/19443994.2012.719324

Ghosh, A., Dastidar, M.G. and Sreekrishnan, T.R. 2014. Biosorption and biodegradation of chromium complex dye using Aspergillus species. J. Hazard. Toxic Radioact. Waste. 18(4): 
1-9. doi:10.1061/(ASCE)HZ.21535515.0000230

Gonzalo, G., Colpa, D.I., Habibb, M.H.M. and Fraaiji, M.W. 2016. Bacterial enzymes involved in lignin degradation. J. Biotechnol. 236: 110-119. doi:10.1016/j.jbiotec.2016.08.011

Haug, W., Schmidt, A., Nortemann, B., Hempel, D.C., Stolz, A. and Knackmuss, H.J. 1991. Mineralization of the sulfonated azo dye Mordant Yellow 3 by a 6-aminonaphthalene-2sulfonate-degrading bacterial consortium. Appl. Environ. Microbiol. 57: 3144-3149. doi: 0099-2240/91/ $113144-06 \$ 02.00 / 0$

Hunger, K. 2003. Industrial Dyes: Chemistry, Properties and Application. Weinheim: Wiley-VCH, Verlag.

Jadhav, J.P., Kalyani, D.C., Telke, A.A., Phugare, S.S. and Govindwar, S.P. 2010. Evaluation of the efficacy of a bacterial consortium for the removal of color, reduction of heavy metals, and toxicity from textile dye effluent. Bioresour. Technol. 101: 165-173. doi:10.1016/j.biortech.2009.08.027

Jadhav, S.B., Surwase, S.N., Kalyani, D.C., Gurav, R.G. and Jadhav, J. P. 2012. Biodecolorization of azo dye Remazol Orange by Pseudomonas aeruginosa $\mathrm{BCH}$ and toxicity (Oxidative Stress) reduction in Allium cepa root cells. Appl. Biochem. Biotechnol. 168: 13191334. doi:10.1007/s12010-012-9860-z

Kabra, A.N., Khandare, R.V., Waghmode, T.R. and Govindwar, S.P. 2011b. Differential fate of metabolism of a sulfonated azo dye Remazol Orange 3R by plants Aster amellus Linn., Glandularia pulchella (Sweet) Tronc. and their consortium. J. Hazard. Mater. 190: 424-431. doi:10.1016/j.jhazmat. 2011.03.065

Kadam, A.A., Telke, A.A., Jagtap, S.S. and Govindwar, S.P. 2011. Decolorization of adsorbed textile dyes by developed consortium of Pseudomonas sp. SUK1 and Aspergillus ochraceus NCIM-1146 under solid state fermentation. J. Hazard. Mater. 189(1): 486-494. doi:10.1016/j.jhazmat.2011.02.066

Kalyani, D.C., Patil, P.S., Jadhav, J.P. and Govindwar, S.P. 2008. Biodegradation of reactive textile dye Red BLI by an isolated bacterium Pseudomonas sp. SUK1. Bioresour. Technol. 99: 46354641. doi:10.1016/j.biortech.2007.06. 058

Lade, H., Govindwar, S. and Paul, D. 2015. Mineralization and detoxification of the carcinogenic azo dye Congo Red and real textile effluent by a poly urethane foam immobilized microbial consortium in an upflow column bioreactor. Int. J. Environ. Res. Public Health. 12: 68946918. doi:10.3390/ijerph120606894

Lade, H.S., Waghmode, T.R., Kadam, A.A. and Govindwar, S.P. 2012. Enhanced biodegradation and detoxification of disperse azo dye Rubine GFL and textile industry effluent by defined fungal-bacterial consortium. Int. Biodeter. Biodegrad. 72: 94-107. doi: 10.1016/j.ibiod.2012.06.001

Lemr, K., Holcapek, M., Jandera, P. and Lycka, A. 2000. Analysis of metal complex azo dyes by high- performance liquid chromatography/ electrospray ionization mass spectrometry and multistage mass spectrometry. Rapid Commun. Mass Spectrom. 14: 18811888. doi:10.1002/1097-0231(2000103 0)

Mabrouk, M.E.M. and Yusef, H.H. 2008. Decolorization of Fast Red by Bacillus subtilis HM. J. Appl. Sci. Res. 4: 262269.

Patel, D.K., Tipre, D.R. and Dave, S.R. 2017. Enzyme mediated bacterial biotransformation and reduction in toxicity of 1:2 chromium complex AB193 and AB194 dyes. J. Taiwan Inst. 
Chem. $\quad$ Eng., $\quad 77$ : 1-9. doi:org/10.1016/j.jtice.2017.02.027

Patel, D.K., Tipre, D.R. and Dave, S.R. 2017. Selection and development of efficient consortia for decolorization of metal complex dyes. Toxicol. Environ. Chem. 99(2): 252-264. doi:10.1080/02772248. 2016.1178264

Patel, T.L., Patel, B.C., Kadam, A., Tipre, D.R. and Dave, S.R. 2015. Application of novel consortium TSR for treatment of industrial dye manufacturing effluent with concurrent removal of ADMI, COD, heavy metals and toxicity. Water Sci. Technol. 71(9): 1293-1300. doi: 10.2166/wst.2015.073

Patil, S.M., Chandanshive, V.V., Rane, N.R., Khandare, R.V., Watharkar, A.D. and Govindwar, S.P. 2016. Bioreactor with Ipomoea hederifolia adventitious roots and its endophyte Cladosporium cladosporioides for textile dye degradation. Environ. Res. 146: 340349. doi:10.1016/j.envres.2016.01.019

Santos, G.C. and Corso, C.R. 2014. Comparative analysis of azo dye biodegradation by Aspergillus oryzae and Phanerochaete chrysosporium. Water Air Soil Pollut. 225: 2026, 1-11. doi: 10.1007/s11270-014-2026-6

Saratale, R.G., Saratale, G.D., Chang, J.S. and Govindwar, S.P. 2011. Bacterial decolorization and degradation of azo dyes: A review. J. Taiwan Inst. Chem. Eng. 42: 138-157. doi:10.1016/j.jtice. 2010.06.006

Saratale, R.G., Saratale, G.D., Chang, J.S. and Govindwar, S.P. 2009. Ecofriendly degradation of sulfonated diazo dye C.I. Reactive Green 19A using Micrococcus glutamicus NCIM-2168. Bioresour. Technol. 100: 3897-3905. doi:10.1016/ j.biortech.2009.03.051

Shah, P.D., Dave, S.R. and Rao, M.S. 2012. Enzymatic degradation of textile dye Reactive Orange 13 by newly isolated bacterial strain Alcaligenes faecalis PMS-1. Int. Biodeter. Biodegrad. 69: 41-50. doi:10.1016/j.i biod.2012.01.002

Sheth, N.T., Dave and S.R. 2009. Optimisation for enhanced decolourization and degradation of Reactive Red BS C.I. 111 by Pseudomonas aeruginosa NGKCTS. Biodegradation. 20: 827-836. doi:10.1007/s10532-009-9270-2

Shi, X., Liu, Q., Ma, J., Liao, H., Xiong, X., Zhang, K., Wang, T., Liu, X., Xu, T., Yuan, S., Zhang, X. and Zhu, Y. 2015. An acid-stable bacterial laccase identified from the endophyte Pantoea ananatis $\mathrm{Sd}-1$ genome exhibiting lignin degradation and dye decolorization abilities. Biotechnol. Letters. 37(11): 2279-2288. doi:10.1007/s10529-0151914-1

Shrivastava, V. S. 2012. Photocatalytic degradation of methylene blue dye and chromium metal from wastewater using nano crystalline $\mathrm{TiO}_{2}$ semiconductor. Arch. Appl. Sci. Res. 4(3): 1244-1254.

Solis, M., Solis, A., Perez, H. I., Manjarrez, N. and Flores, M. 2012. Microbial decoloration of azo dyes: A review. Process Biochem. 47: 1723-1748. doi:10.1016/j.procbio.2012.08.014

Travkin, V., Baskunov, B.P., Golovlev, E.L., Boersma, M.G., Boeren, S., Vervoort, J., van Berkel, W.J.H., Rietjens, I. M.C.M. and Golovleva, L.A. 2002. Reductive deamination as a new step in the anaerobic microbial degradation of halogenated anilines. FEMS Microbiol. Lett. 209: 307-312. doi:10.1111/j.15746968.2002.tb11149.x

Vogel, I.A. 1962. Textbook of quantitative inorganic analysis. $3^{\text {rd }}$ ed. ELBS and Longman, London.

Wang, F., Grundmann, S., Schmid, M., Dorfler, U., Roherer, S., Munch, J.C., Hartmann, A., Jiang, X. and Schroll, R. 2007. Isolation and characterization of 
1,2,4-trichlorobenzene mineralizing Bordetella sp. and its bioremediation potential in soil. Chemosphere. 67: 896902.

doi:10.1016/j.chemosphere.2006.11.019

$\mathrm{Xu}$, M., Guo, J. and Sun, G. 2007. Biodegradation of textile azo dye by Shewanella decolorationis S12 under microaerophilic conditions. Appl.
Microbiol. Biotechnol. 76: 719-726. doi:10.1007/s00253-007-1032-7

Zimmermann, T., Kulla, H.G. and Leisinger, T. 1982. Properties of purified Orange II azoreductase, the enzyme initiating azo dye degradation by Pseudomonas KF46203. Eur. J. Biochem. 129: 197203. doi:10.1111/j.1432-1033.1982.tb0 7040

\section{How to cite this article:}

Patel, D.K., D.R. Tipre, T.L. Patel, A. Kadam, S.A. Agarwal and Dave, S.R. 2018. Elucidation of Biochemical Mechanism Involved in Microbial Degradation of 1:1 Metal Complex Dye Containing Simulated Wastewater. Int.J.Curr.Microbiol.App.Sci. 7(03): 2774-2789. doi: https://doi.org/10.20546/ijcmas.2018.703.320 